\title{
TACROLIMUS IN REFRACTORY LUPUS NEPHRITIS
}

Vanessa Posener de Andrade ${ }^{1, \star}$, Guilherme Guimarães Moreira Balbi ${ }^{1}$, Isabele Parente de Brito Antonelli ${ }^{1}$, Nestor José de Souza Barreto Neto ${ }^{1}$, Pablo Vinicius da Fonseca ${ }^{1}$, Sandra Gofinet Pasoto ${ }^{1}$, Danieli Castro Oliveira de Andrade ${ }^{1}$, Emily Figueiredo Neves Yuki $^{1}$, Eduardo Ferreira Borba Neto ${ }^{1}$, Eloisa Silva Dutra de Oliveira Bonfá1 ${ }^{1}$ Luciana Parente Costa Seguro ${ }^{1}$

1.Universidade de São Paulo, São Paulo (SP), Brazil.

${ }^{\star}$ Corresponding author: vanessa.posener@hc.fm.usp.br

\section{BACKGROUND}

Tacrolimus (TAC) has emerged as an alternative therapy for lupus nephritis (LN) in recent years, but data are almost exclusively in Asian populations. Our purpose was to evaluate effectiveness and safety of TAC in refractory lupus nephritis in a Brazilian lupus tertiary center.

\section{METHODS}

Systemic lupus erythematosus (SLE) patients (ACR criteria) who received six months of induction therapy with TAC for refractory LN from 2016 to 2021 were included. Refractoriness was defined as persistence of $24 \mathrm{~h}$ proteinuria $>800 \mathrm{mg}$ after induction therapy with cyclophosphamide and/or mycophenolate mofetil (MMF). Clinical, laboratorial, and therapy data were evaluated at baseline (start of TAC therapy) and after six months (T6) by chart review. The median daily dose of tacrolimus was $4 \mathrm{mg}$ (1-6 mg/day). Exclusion criteria was baseline $\mathrm{CrCl}<60 \mathrm{~mL} / \mathrm{min} / 1.73 \mathrm{~m}^{2}$. Complete renal response (CRR): urine $\mathrm{P} / \mathrm{C}$ ratio $<50 \mathrm{mg} / \mathrm{mmol}$ and normal GFR; partial renal response (PRR): $>50 \%$ reduction in proteinuria to subnephrotic levels and normal GFR (EULAR definitions).

\section{RESULTS}

Twenty-eight SLE patients were included: 85.7\% female, $71.4 \%$ Caucasian, and mean age was $38.3( \pm 7.9)$ years. Comparative baseline and T6 data are shown in Table 1 . Serum creatinine ( $0.78 \pm 0.24 \mathrm{vs} .0 .87 \pm 0.28 \mathrm{mg} / \mathrm{dL}), C 3(84.6 \pm 31.75 \mathrm{vs} .89 .33 \pm 22.57 \mathrm{mg} / \mathrm{dL})$ and C4 (15.28 \pm 10.07 vs. $14.47 \pm 4.97 \mathrm{mg} / \mathrm{dL})$ levels remained stable at T6 compared to baseline $(p>0.05)$. Fifteen $(53 \%)$ patients received multitarget therapy (associated with MMF) and 25 (89.3\%) were on antiproteinuric therapy; 12 (42.85\%) patients required optimization of antihypertensive drug regimens and $5(17.9 \%)$ had creatinine increase over $30 \%$ of baseline. Twenty-one (75\%) patients showed reduction in proteinuria levels $\geq 50 \%$ at T6 compared to baseline. At T6, 15 (53.6\%) patients had $24 \mathrm{~h}$ proteinuria < $0.8 \mathrm{~g}, 19$ (67.9\%) reached PRR and 10 (35.7\%) achieved CRR.

Table 1. Comparative baseline and T6 data.

\begin{tabular}{cccc} 
& Baseline $(\mathrm{n}=29)$ & $\mathrm{T} 6(\mathrm{n}=29)$ & $\mathrm{P}$ \\
\hline 24 h proteinuria $(\mathrm{g})$ & $2.45 \pm 1.65$ & $1.01 \pm 0.99$ & $<0.001^{\star}$ \\
\hline Albumin $(\mathrm{mg} / \mathrm{dL})$ & $3.43 \pm 0.59$ & $3.70 \pm 0.58$ & 0.089 \\
\hline SLEDAI & $12(4-29)$ & $4(0-29)$ & $0.008^{\star}$ \\
\hline Anti-dsDNA+ & $22(78.56 \%)$ & $15(45.5 \%)$ & 0.089 \\
\hline Prednisone (mg/day) & $20(7.5-60)$ & $15(0-40)$ & $0.011^{\star}$ \\
\hline
\end{tabular}

Data expressed as mean \pm SD, median (range), or $\mathrm{N}$ (percentage). * Significant.

\section{CONCLUSION}

Tacrolimus was safe and effective in proteinuria control and prednisone sparing in a multiracial western population with refractory LN. More research is needed to confirm the potential and long-term safety of tacrolimus in SLE patients.

\section{KEYWORDS}

Systemic lupus erythematosus, Tacrolimus, Lupus nephritis.

Realização: 